\title{
Библиографические ссылки
}

1. Былов В. Н. Основы сортоизучения и сортооценки декоративных растений при интродукции. Бюл. Гл. ботан. сада. М.: 1971. Вып. 81. С. 69-77.

2. Былов В. Н., Карписонова $\boldsymbol{P}$. А. Принципы создания и изучения коллекции малораспространённых декоративних многолетников. Бюл. Гл. ботан. сада. М.: 1978. Вып. 107. С. 77-82.

3. Горницкая И. П. Интродукция тропических и субтропических растений, ее теоретические и практические аспекты. Донецк : Донеччина, 1995. 302 с.

4. Домницька I. Л. Новий метод укорінення листкових живців сортів і видів Saintpaulia H. Wendl. Рослини та урбанізація: мат. 5 міжнар. конф. Дніпропетровськ (Україна), 2016. С. 103-105.

5. Макуни Б. М., Клевенская Т. М. Сенполии. М. : Астрель, 2001. 112 с.

6. Каталог растений ботанического сада Днепропетровского национального университета имени Олеся Гончара. В. Ф. Опанасенко, А. Н. Кабар, Н. В. Мартынова, И. Л. Домницкая и др. Д. : Лира, 2015. С. 191-197.

7. Справочник Американского общества любителей африканских фиалок для выращивающих фиалки, участников выставок и судей. Пер. с англ. В. Калгина. М.: Альварес Паблишинг, 2004. 128 с.

8. Шевченко В. В., Гриних Л. И. Химерность у растений. М. : Наука, 1981. 212 с.

9. Alekseeva A., Lykholat Yu., Khromykh N., Boroday E. Specificity of the cutucular waxes composition of the linden leaves depending on light level in tree crown // Abstract book of 3 -d conference of young scientists «Plant biology and biotechnology» (16-18 may 2017, Kyiv, Ukraine). K.: NAY, 2017. C. 20.

10. Baranovski B. , Khromykh N., Karmyzova L., Ivanko I., Lykholat Y. Anyalysis of the alien flora of Dnipropetrovsk province // Biological Bulletin of Bogdan Chmelnitskiy Melitopol State Pedagogical University. 2016. 6 (3). P. 419-429.

11. Klymenko G., Kovalenko I, Lykholat Yu., Khromykh N., Didur O., Alekseeva A. The integral assessment of the rare plant populations. Ukrainian Journal of Ecology. 2017. 7(2). P. 201-209.

12. Lykholat Y., Khromyk N., Ivan'ko I., Kovalenko I., Shupranova L., Kharytonov M. Metabolic responses of steppe forest trees to altirude-associated local environmental changes // Agriculture \& Forestry. Vol. 62, Issue 2: Podgorica. 2016. P. 163-171.

13. Lykholat Y., Alekseeva A., Khromykh N., Ivan'ko I., Kharytonov M., Kovalenko I. Assessment and prediction of viability and metabolic activity of TILIA PLATYPHYLLOS in arid steppe climate of Ukraine. Agriculture and Forestry. Volume 62. Issue 3: Podgorica. 2016. - P. 65-71.

14. Prisedsky Y., Kabar A., Lykholat Y., Martynova N., Shupranova L. Activity and isoenzyme composition of peroxidase in Japanese quince vegetative organs under steppe zone conditions. 2017. Vol. 63. No. 2. P. 185-192.

15. AVSA Handbook for Growers, Exhibitors and Judges [PDF version] / Available at: http://www.avsa.org/2016.pdf.

Надійшла до редколегії

В. М. Савосько, Н. В. Товстоляк

Криворізький державний педагогічний університет

\section{РОЗВИТОК І СУЧАСНИЙ СТАН САДІВ ТА ПАРКІВ КОЛИШНІХ ЗАЛІЗНИХ РУДНИКІВ КРИВОРІЖЖЯ}

У роботі на основі аналізу архівних та літературних джерел, а також польових досліджень проаналізовано розвиток та сучасний стан одного саду та восьми парків

(C) В. М. Савосько, Н. В. Товстоляк, 2018 
колишніх залізних рудників Криворіжжя. Встановлено, що лише один об'єкт озеленення (сад готелю «Park House» - приватна власність) має повністю доглянуту територію, збалансовану структуру та динамічно розвивається.

Попри зручне розташування, високий соціальний статус районних парків (парки «Шахтарський» і «Саксаганський») та провідного парку мікрорайону (парк «Тернівський»), спостерігається часткова втрата ними запроектованих функцій та недостатній догляд окремих територій. Парки «Затишний», біля палацу культури шахти «Родіна» та «Руданівський» частково втратили соціальну значущість, що негативно позначилося на їх сучасному стані. Спортивний парк ім. Суворова та парк шахти «Гвардійська», внаслідок припинення регулярних робіт та догляду, деградують.

Ключові слова: деревно-чагарникові види, сади та парки, Криворіжжя.

В. М. Савосько, Н. В. Товстоляк

Криворожский государственный педагогический университет

\title{
РАЗВИТИЕ И СОВРЕМЕННОЕ СОСТОЯНИЕ САДОВ И ПАРКОВ БЫВШИХ ЖЕЛЕЗНЫХ РУДНИКОВ КРИВОРОЖЬЯ
}

В работе на основе анализа архивных и литературных источников, а также полевых исследований проанализировано развитие и современное состояние одного сада и восьми парков бывших железных рудников Криворожья. Установлено, что только один объект озеленения (сад отеля «Park House» - частная собственность) имеет полностью ухоженную территорию, сбалансированную структуру и динамично развивается. Несмотря на удобное расположение, высокий социальный статус районных парков (парки «Шахтерский» и «Саксаганский») и ведущего парка микрорайона (парк «Терновской») наблюдается частичная потеря ими запроектированных функций и недостаточный уход за отдельными территориями. Парки «Уютный», возле дворца культуры шахты «Родина» и «Рудановский» частично утратили социальную значимость, что негативно сказалось на их современном состоянии. Спортивный парк им. Суворова и парк шахты «Гвардейская», в результате прекращения регулярных работ ухода, деградируют.

Ключевые слова: древесно-кустарниковые насаждения, сады и парки, Криворожье.

\author{
V. M. Savosko, N. V. Tovstolyak \\ Kryvyi Rih State Pedagogical University
}

\section{DEVELOPMENT AND MODERN STATE OF GARDENS AND PARKS OF FORMER IRON MINES AT KRYVORIZHZHYA}

The aim of the study: to analyze the development and modern state of the gardens and parks of the former iron mines at Kryvorizhzhya.

Materials and methods. During 2013-2017, nine objects of landscape and park at Kryvorizhzhya were explored. Among them were: 1) seven operating parks («Ternivskyi», «Shakhtarskyi», «Zatyshnyi», Suvorov sports park, park near the Palace of Culture of mine «Rodina», «Saksahanskyi», «Rudanivskyi»), one abandonment park in the exclusion zone (Park of mine «Hvardiiska»), one garden of hotel «Park House» (private property). Initially, a historical description of the above objects of landscaping, as well as their structural and functional organization was presented. In the future, in the field conditions, by the route method, the present state of the gardens and parks was investigated and the general level of development of their shoots and shrubs was determined.

Results and conclusions. System creation of gardens and parks on the territory of former iron mines of Kryvorizhzhya began in the 30's of the 20th century, and became massive in the 50's and 60's of the twentieth century. After 80 years of the 20th century there was a change in their owners, a decrease in their social status and the cessation of necessary expenses for their maintenance.

At the beginning of the XXI century, among the gardens and parks of the former iron mines of Kryvorizhzhya, in the best condition is the Garden of the Hotel «Park House», which incorporates modern garden and park technology. 
Now the parks «Shakhtarskyi» and «Saksahanskyi» have the official status - the district parks of the city. The park «Ternivskyi» has the informal status of the main park of the neighborhood.

That's why all these parks are actively used, and their territory is relatively wellgroomed. Simultaneously others Parks («Zatyshnyi», near the Palace of Culture of mine «Rodina» and «Rudanivskyi») turned out to be less popular for visitors and less for owners. Therefore, their area and plantations - only partially well-groomed. Suvorov sports park, as well as Park of mine «Hvardiiska» are most de-structured. Therefore, their territory is practically unhealthy and the species composition of trees and shrubs degrades.

In general, the current state of the gardens and parks of the former iron mines of Kryvorizhzhya depends on "social demand», the degree of their remoteness from residential areas and containment technologies. The obtained results can be used during the development and substantiation of the system of measures for optimization of existing and designing of new garden and park plantings in industrial regions. In further research it is expedient to analyze the environmental conditions of the gardens and parks of the former iron mines of Kryvorizhzhya, as well as the floristic composition and the condition of woody-shrub species. In addition, it makes sense to expand the list of these mines and explore the gardens and parks of inactive mines to them May 1 and Ingulets.

Keywords: tree and shrub plantations, gardens and parks, Kryvorizhzhya.

У сучасних промислових регіонах деревно-чагарникові рослини відіграють значну роль в оптимізації середовища існування людини. Завдяки їм відбувається покращення міського мікроклімату та упорядкування архітектурно-планувальної структури міста. Крім того, дерева та чагарники позитивно впливають на психічний стан людей в умовах емоційно-навантаженого ритму життя $[6,7,12]$. Однак, у промислових регіонах, котрі розташовані у Степовій зоні, спостерігається прискорений розвиток, передчасне старіння цих рослин та зменшення їх фітомеліоративної ефективності. Тому на початку XXI ст. залишається актуальним дослідження сучасних садово-паркових насаджень у всіх промислових регіонах $[2$, $10,15]$.

У Криворізькому гірничо-металургійному регіоні проблема озеленення міста неодноразово ставала предметом наукових вишукувань, зокрема викладачів кафедри ботаніки та екології Криворізького державного педагогічного університету $[3,4,10,11,12,13,14]$ та співробітників Криворізького ботанічного саду [16, $18,19]$. Проте, вивченню розвитку садів і парків регіону, а також екологічній обумовленості сучасного стану деревно-чагарникових видів приділялася значно менша увага.

Серед об’ єктів озеленення Криворіжжя особливої уваги заслуговують сади та парки колишніх залізних рудників, які були закладені у 30-50-х роках XX ст. При цьому слід зазначити, що для їх створення були залучені значні кошти та впроваджені найкращі досягнення тогочасної наукової думки $[5,8,9]$. Однак у подальшому, розвиток цих об'єктів озеленення відбувався за сценаріями і прогресу, і регресу. Як наслідок, сучасні сади та парки колишніх залізних рудників Криворіжжя являють собою унікальну наукову платформу для встановлення результатів багатолітнього ботаніко-екологічного експерименту з екологічної обумовленості флористичного складу та сучасного стану деревно-чагарникових видів. Першим кроком таких досліджень є всебічне екологічне та історичне вивчення територій цих садів і парків.

Мета роботи - проаналізувати розвиток та сучасний стан садів і парків колишніх залізних рудників Криворіжжя.

Матеріали та методи досліджень. Протягом 2013-2017 років було досліджено дев'ять об'єктів садово-паркового господарства Криворіжжя, серед них сім діючих парків («Тернівський», «Шахтарський», «Затишний», спортивний парк імені Суворова, парк біля палацу культури шахти «Родіна», «Саксаганський», «Ру- 
данівський»), один занедбанний парк у зоні відчуження (парк шахти «Гвардійська»), один сад готелю «Park House» (приватна власність). Спочатку була наведена історична характеристика зазначених об'єктів озеленення, а також їх структурно-функціональна організація. У подальшому, у польових умовах маршрутним методом досліджено сучасний стан садів і парків та з'ясовано загальний рівень розвитку їх деревно-чагарникових насаджень.

Результати та їх обговорення. Перші спроби створення об' єктів садово-паркового господарства (у сучасному розумінні) поруч із залізними рудниками Криворіжжя відбулися ще за часів «залізної лихоманки» - на початку XX ст. Однак ці спроби, у більшості випадків, були дуже малочисельними. Системне та масштабне озеленення територій рудників регіону розпочалося з 30 -тих років XX ст. При цьому найбільший розквіт їх садів та парків припадає на 50-60-ті роки XX ст. Саме у цей час виключно рудники видобували основну масу залізної руди у регіоні. Надалі (у 70-80-тих роках XX ст.) були збудовані потужні гірничо-збагачувальні комбінати та нові житлові масиви. Як наслідок, відокремлені шахтарські селища стали фактичною частиною міста. Тому сади та парки рудників отримали інший соціальний статус. У 90-тих роках XX ст. нові приватні власники рудників активно сприяли юридичному закріпленню цього статусу $[5,8,17]$.

Парк «Тернівський» - районний парк культури та відпочинку, створений у 1963 році, знаходиться на території колишнього рудника Колачевського. За радянських часів цей рудник мав назву ім. Орджонікідзе та ім. Леніна [8], що знайшло своє відображення у назвах цього парку (табл. 1). 3 історичної точки зору, парк «Тернівський» - не перший парк на теренах цього руднику.

Таблиия 1

Історична характеристика садів та парків колишніх залізних рудників Криворіжжя

\begin{tabular}{|c|c|c|c|c|}
\hline \multirow{3}{*}{$\begin{array}{c}\text { Історична назва } \\
\text { залізного рудника }\end{array}$} & \multicolumn{4}{|c|}{ Парк/сад } \\
\hline & \multirow{2}{*}{$\begin{array}{c}\text { рік ство- } \\
\text { рення }\end{array}$} & \multicolumn{2}{|c|}{ назва } & \multirow{2}{*}{ Площа, га } \\
\hline & & історична & сучасна & \\
\hline Колачевського & 1963 & $\begin{array}{c}\text { парк рудника } \\
\text { ім. Орджонікідзе }\end{array}$ & парк «Тернівський» & 20 \\
\hline Олександрівський & 1936 & $\begin{array}{c}\text { парк рудника } \\
\text { iм. Р. Люксембург }\end{array}$ & $\begin{array}{c}\text { парк шахти } \\
\text { «Гвардійська» }\end{array}$ & 15 \\
\hline Суха Балка & 1950 & $\begin{array}{c}\text { парк рудника } \\
\text { ім. Кагановича }\end{array}$ & парк «Шахтарський» & 43 \\
\hline Новоросійський & 1962 & $\begin{array}{c}\text { парк рудника } \\
\text { iм. Фрунзе }\end{array}$ & $\begin{array}{c}\text { парк } \\
\text { «Затишний» }\end{array}$ & 3,6 \\
\hline Ростковський & 1933 & $\begin{array}{c}\text { парк рудника } \\
\text { iм. «Червоного жовтня» }\end{array}$ & $\begin{array}{c}\text { спортивний парк } \\
\text { iм. Суворова } \\
\end{array}$ & 15 \\
\hline Дубова балка & 1938 & $\begin{array}{l}\text { парк рудника } \\
\text { «Більшовик» }\end{array}$ & $\begin{array}{c}\text { сад готелю } \\
\text { «Park House» }\end{array}$ & 4,0 \\
\hline Шмаковський & 1938 & $\begin{array}{c}\text { парк біля } \\
\text { клубу рудника } \\
\text { ім. К. Лібкнехта }\end{array}$ & $\begin{array}{l}\text { районний парк біля } \\
\text { ПК шахти «Родіна» }\end{array}$ & 5,0 \\
\hline Галковський & 1950 & $\begin{array}{c}\text { парк рудника } \\
\text { ім. Кірова }\end{array}$ & $\begin{array}{c}\text { парк } \\
\text { «Саксаганський» }\end{array}$ & 8,7 \\
\hline Карнаватський & 1930 & $\begin{array}{c}\text { парк рудника } \\
\text { ім. Дзержинського }\end{array}$ & парк «Руданівський» & 7,2 \\
\hline
\end{tabular}

Наприкінці XIX ст. власником та засновником рудника С.М. Колачевським поруч зі своїм маєтком був закладений перший парк. У 20-50-х роках він активно розвивався та використовувався як провідний парк шахтарського селища $[5,8]$.

\footnotetext{
Примітка. ПК - палац культури.
} 
Однак, потім цей парк потрапив у зону відчуження (з причини процесів обвалення гірських порід та грунту над шахтними пустотами) і поступово занепав. Внаслідок техногенного землетрусу 13.06.2010 p [1], парк Колачевського був остаточно зруйнований.

У наш час парк «Тернівський», розташований у межах великого житлового масиву поруч із міською «червоною лінію», структурно та функціонально достатньо організований, має розвинену мережу пішохідних доріжок і чітку симетричну будову (табл. 2).

Таблиия 2

Структурна організація садів та парків колишніх залізних рудників Криворіжжя

\begin{tabular}{|c|c|c|c|c|c|c|c|c|c|}
\hline \multirow[b]{2}{*}{ Сучасна назва } & \multicolumn{3}{|c|}{ Зелені насадження } & \multicolumn{6}{|c|}{ Структурні елементи } \\
\hline & 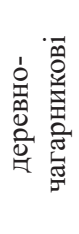 & 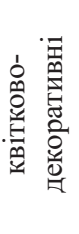 & 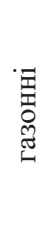 & 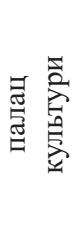 & 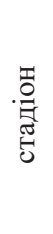 & 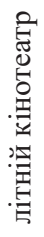 & 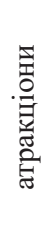 & 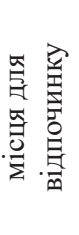 & 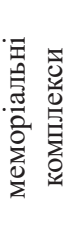 \\
\hline Парк «Тернівський» & ++ & ++ & ++ & ++ & -- & -- & ++ & ++ & -- \\
\hline $\begin{array}{c}\text { Парк шахти } \\
\text { «Гвардійська» }\end{array}$ & ++ & +- & +- & +- & ++ & +- & -- & +- & -- \\
\hline Парк «Шахтарський» & ++ & ++ & ++ & ++ & ++ & +- & ++ & ++ & ++ \\
\hline Парк «Затишний»» & ++ & ++ & ++ & ++ & -- & +- & +- & +- & -- \\
\hline $\begin{array}{c}\text { Спортивний парк } \\
\text { iм. Суворова }\end{array}$ & ++ & +- & +- & -- & ++ & -- & -- & +- & -- \\
\hline Сад готелю «Park House» & ++ & ++ & ++ & +- & -- & +- & -- & ++ & -- \\
\hline $\begin{array}{c}\text { Районний парк } \\
\text { біля ПК ш. «Родіна» }\end{array}$ & ++ & ++ & ++ & ++ & ++ & -- & +- & ++ & ++ \\
\hline Парк «Саксаганський» & ++ & ++ & ++ & ++ & ++ & +- & ++ & ++ & -- \\
\hline Парк «Руданівський» & ++ & ++ & ++ & ++ & -- & +- & +- & ++ & ++ \\
\hline
\end{tabular}

У наш час у парку «Тернівський» переважають напіввідкриті простори зріджених зелених насаджень із груповим або рівномірним розміщенням, а також відкриті простори коротких перспектив, зустрічаються як окремі групові композиції, так і рядові насадження та алеї. У парку також спостерігаються ознаки часткового доповнення видового складу, постійного догляду частини, прилеглої до будинку культури, вона найбільш пристосована для виконання рекреаційних функцій. Квітково-газонні насадження становлять малу частку відносно загальної площі цього парку. У сучасному стані деревно-чагарникових насаджень парку домінують два процеси: 1) відносний розвиток на прилеглій до палацу культури території (повільне відновлення і незначне поновлення видового складу), 2) деградація на віддалених територіях (здичавіння, утворення порості, порушення гідрологічного балансу через осушення двох ставків).

Парк шахти «Гвардійська» - створений у 1936 р. на території колишнього Олександрівського рудника як парк культури та відпочинку. За радянських часів мав назву парку рудників ім. Рози Люксембург та «Гвардійського». До кінця 60-х років XX ст. активно використовувався як провідний об'єкт озеленення шахтарського селища (табл. 1) [5, 8, 17].

Важливо наголосити, що парк шахти «Гвардійська» був дуже вдало розташований на лівому схилі та у низині балки Рокувата поруч зі стадіоном і колишнім

Примітка. «++» - наявні у радянський та сучасний період, «+-» - історично були закладені, але на даний момент вже відсутні, «--» - не запроектовані. 
палацом культури рудника. Свого часу архітектори парку вміло використали рельєф схилу для формування системи оглядових доріжок та стежок у пейзажному стилі. Однак, стратегічний вибір місця для цього парку виявився вкрай недалекоглядним. Тому, що починаючи 3 70-тих років XX ст., парк шахти «Гвардійська» разом із прилеглими територіями поступово занепадає, оскільки виявився розташованим поруч із зоною провалів. У наш час палац культури зруйнований, парк дуже занедбаний та фактично знаходиться на стадії деградації. На його території переважають напіввідкриті простори зріджених насаджень із рівномірним їх розміщенням, групові композиції майже відсутні. Деревно-чагарникові насадження поступово дичавіють, випадають менш стійкі види, практично відсутні чагарники, спостерігається великий відсоток поновлення за рахунок самосівів більш стійких видів.

Парк «Шахтарський» - парк культури та відпочинку, що знаходиться на території колишнього рудника «Суха Балка», був закладений у 1950 році. За радянських часів він мав назву парку рудників ім. Кагановича та ім. XX-го Партз'їзду, а також парк 50-річчя Радянської України $[8,9]$. Цей парк розташований по «червоній лінії, поруч із житловим масивом, повністю структурно та функціонально організований, на його території знаходиться меморіальний комплекс (табл. 1, табл. 2). Північно-східна частина парку розташована на правому березі Кресівського водосховища. У східній частині парку є дві невеликі водойми штучного походження.

Парк «Шахтарський» має розвинену променеву мережу пішохідних доріжок. При цьому у південній, східній та центральній частинах парку переважають напіввідкриті простори зріджених насаджень із груповим та рівномірним їх розміщенням. Відкритий простір коротких перспектив зустрічається у південно-західній частині, у той час, як напівзакриті простори рядових насаджень, переважно із рівномірним їх розміщенням, поширені у північно-західній, південно-східній та східній частинах парку.

Парк «Затишний» - парк культури та відпочинку, розташований на території колишнього рудника Новоросійського, був створений 1962 року (табл. 1). За радянських часів рудник мав назву ім. Фрунзе, що позначилося на історичній назві парку. Перший парк (сквер) руднику був розташований значно західніше [4]. Однак після будівництва палацу культури рудника та закладки нового парку старий поступово деградував.

Парк «Затишний» розміщений на лівому високому березі балки Глеюватої по «червоній лінії», поруч із житловим масивом, має променеву симетрію пішохідних доріжок. Більша частина його дерев та чагарників скомпонована відкритими просторами коротких перспектив, крім східної частини - там напівзакриті простори рядових насаджень із рівномірним розміщенням (недоглянута частина із самосівом).

У наш час спостерігається поступова деградація парку «Затишний» як рекреаційного осередку, втрачена більша частина структурних елементів, доглянута лише припалацова територія. Переважає незначне поновлення шляхом самосіву, частка квітників незначна.

Спортивний парк імені Суворова був створений у 1933 році як парк культури та відпочинку на теренах колишнього рудника Ростковського, який за радянських часів спочатку мав назву рудник ім. «Червоного Жовтня» потім ім. «Комінтерну» $[5,8,9,17]$. Важливо зазначити, що територія парку розташована у заплаві p. Саксагань - його екологічні умови дуже сприятливі для росту та розвитку насаджень. (табл. 1).

Парк дуже постраждав під час Другої світової війни, тому зазнав значної реконструкції, зокрема був побудований спортивний стадіон. У період максимального розквіту у 50-70-тих роках XX ст. у спортивному парку ім. Суворова функці- 
онували літній театр, павільйони, різноманітні атракціони, дитяча ігрова площадка (табл. 2). Крім того, його територію прикрашали високодекоративні клумби та смарагдові газони. Однак, у подальшому парк фактично був залишений поза увагою. Негативним чином на стан цього об’єкту озеленення також вплинула його віддаленість від житлових масивів.

На теперішній час лише північна територія спортивного парку ім. Суворова, що розташована поруч зі стадіоном, регулярно доглядається. Тоді як його південно-західна частина була знищена через недбалість під час проведення ремонтних робіт системи шахтного водовідведення. Центрально-західній частині парку притаманні залишки напівзакритих рядових насаджень із рівномірним розміщенням (присутній самосів, вирівняний по видовій та віковій структурі). У південній та східній - напіввідкриті простори зріджених насаджень, переважно рядових.

Cad готелю «Park House» - знаходиться на території колишнього рудника «Дубова балка», який за радянських часів мав назву ім. Сталіна та «Більшовик» (табл. 1). Свого часу на території саду знаходився спеціальний гуртожиток, де зупинялися під час своїх приїздів до міста провідні радянські та комуністичні діячі. Також у межах саду знаходився Будинок наукової та технічної пропаганди/творчості $[8,9,17]$. Територія саду частково знаходиться в заплаві у. Саксагань, розташована поруч зі старою «червоною лінію», проте віддалена від сучасних житлових масивів.

У наш час сад готелю «Park House» має повну групу зелених насаджень: деревно-чагарникових, квітково-декоративних та газонів. Однак його структурна організація не передбачена через малу площу та функціональне призначення (табл. 2). На території саду розвинена променева система пішохідних доріжок із сучасним твердим покриттям та обладнана автостоянка.

Саду «Park House» притаманні великі простори із короткими перспективами, насадження композиційно оформлені, переважають високодекоративні види, які знаходяться у доглянутому стані.

Районний парк біля Палащу культури шахти «Родіна» - парк культури та відпочинку, розміщений на території колишнього рудника Шмаковського поблизу старої «червоної лінії» та житлового масиву колишнього шахтарського селища. За радянських часів цей рудник мав назви спочатку ім. Карла Лібкнехта, потім «Батьківщина», що позначалося на назвах парку $[5,8,9]$. В окремих публікаціях [4] висловлюється припущення, що спочатку був створений рудничний сквер (1914 р.), сад при рудоуправлінні (1936 р.) проте їх місцезнаходження достовірно невідоме.

Теперішній вигляд парку біля Палацу культури шахти «Батьківщина» був сформований садово-парковими насадженнями, починаючи з 1950 р. Максимальний розквіт цього парку припав на 60 -ті роки XX ст. У той час на його території були фонтан, літня відкрита естрада, скульптури, лавки [4]. Справжньою прикрасою парку були зелені альтанки, які були сформовані за допомогою тамариксів (Tamarix L.) та верб (Salix L). Однак у подальшому парк поступово втратив свою актуальність для рудника, що зумовило істотне зменшення інтенсивності робіт догляду та брак коштів для його розвитку. У наш час парк біля Палацу культури шахти «Батьківщина» має хрестоподібну мережу пішохідних доріжок та меморіальний комплекс. Наразі у ньому домінують відкриті простори коротких перспектив, композиційні групи оформлені слабко, переважають рядові насадження, солітери та алеї. Зелені альтанки як вдалий композиційний прийом відсутні. Структурна організація збережена, проте втрачені такі елементи, як літній кінотеатр та атракціони (як можлива альтернатива - дитячий майданчик). Загалом, територія парку відносно доглянута, однак він потребує поновлення видового складу, що практично не відбувається. Процес самооновлення також не спостерігається че- 
рез постійне санітарне зачищення. У перспективі все це може призвести до поступового зникнення об'єкту озеленення.

Парк «Саксаганський» - парк культури та відпочинку, розташований на колишній території рудника Галковського, який мав назву ім. Кірова та ім. Артема, що відзначалося на назвах парку. За літературними даними $[5,9]$, на території руднику перший парк був створений ще на початку XX ст., однак немає достовірної інформації про його місцезнаходження. На сучасному місці парк Саксаганський був закладений на початку 50 -тих років XX ст. Його територія розташована на високому березі р. Саксагань, поруч із «червоною лінією» та житловими масивами (табл. 1).

У наш час парк Саксаганський, як провідний районний парк, є основним місцем проведення різноманітних районних святкових заходів. Він чітко структурований на зони фізичної культури і спорту, тихого відпочинку, є дитячий майданчик (табл. 2). Крім того, парк має розвинену променеву мережу пішохідних доріжок. Усі його частини, крім західної, включають відкриті простори коротких перспектив з елементами композицій та рядових насаджень. Західній частині парку притаманні напівзакриті простори рядових насаджень, переважно за рахунок самосіву.

Парк «Руданівський», створений у 1930 р. як парк культури та відпочинку, знаходиться на території колишнього Карнаватського рудника, який у 30-90-тих роках XX ст. мав назву ім. Дзержинського (табл. 1) і був найпотужнішим рудником Криворіжжя $[8,17]$. Розташований поруч із парком стадіон «Гірник» до 70тих років минулого століття вважався центральним міським стадіоном. Проте у 90-ті роки XX ст. шахти руднику поступово припинили свою діяльність, а його територія була передана на баланс інших підприємств. Приблизно водночас палац культури був переданий Криворізькому міському театру ляльок. Також слід зазначити, що у наш час територія парку віддалена від сучасних «червоних ліній» та житлових масивів.

За проектом парк «Руданівський» мав всі основні структурні компоненти (табл. 2). Однак наразі його зональна структура порушена, функціонують лише зона відпочинку та меморіальний комплекс. Парк має розвинену мережу пішохідних доріжок розосередженого типу.

Територія парку «Руданівський» представлена відкритими просторами коротких перспектив та напіввідкритими просторами зріджених насаджень (характерні елементи - солітери, алеї). Територія парку достатньо доглянута, але цілеспрямованого поновлення видового складу не спостерігаємо.

Загалом, сучасний стан садів та парків колишніх залізних рудників Криворіжжя залежить від «соціального попиту», ступеня їх віддаленості від житлових масивів та технологій балансоутримування. Отримані результати можуть бути використані задля розробки системи заходів з оптимізації існуючих та проектування нових садово-паркових насаджень. У подальших дослідженнях доцільно проаналізувати екологічні умови територій садів та парків колишніх залізних рудників Криворіжжя, а також флористичний склад та стан деревно-чагарникових видів. Крім того, є сенс розширити перелік цих рудників та дослідити сади і парки недіючих рудників ім. 1 Травня та Інгулець.

\section{Висновки}

1. Системне створення садів та парків на теренах колишніх залізних рудників Криворіжжя розпочалося у 30 -тих роках XX ст., та набуло масового характеру у 50-60-ті роки XX ст. Після 80-тих років XX ст. відбулася зміна їх балансоутримувачів, зменшення їх соціального статусу та припинення в повному обсязі витрат на їх утримання.

2. На початок XXI ст. серед садів та парків колишніх залізних рудників Криворіжжя у найкращому стані є сад готелю «Park House», де впроваджені надсу- 
часні садово-паркові технології. Парки «Шахтарський» $\mathrm{i}$ «Саксаганський» мають офіційний статус районних парків міста. Парк «Тернівський» має неофіційний статус основного парку мікрорайону.

3. Парки «Затишний», біля Палацу культури шахти «Родіна» та «Руданівський» виявилися менш затребуваними для відвідувачів та другорядними для балансоутримувачів, а їх територія - лише частково доглянута. Спортивний парк ім. Суворова, а також особливо парк шахти «Гвардійська» $є$ найбільш деструктуровані, територія фактично не доглянута, видовий склад дерев та чагарників деградує.

\section{Бібліографічні посилання}

1. Андрущенко Ю. А., Кутас В. В., Кендзера А. В., Омельченко В. Д. Слабые землетрясения и промышленные взрывы, зарегистрированные на Восточно-Европейской платформе в пределах территории Украины в 2005-2010 гг. // Геофизический журнал. Киев. 2012. № 34 (3). С. 49-60.

2. Бельгард А. Л. Степное лесоведение. Москва. 1971. 336 с.

3. Добровольський I. A. Зелені насадження Криворіжжя // Наукові записки Криворізького державного педагогічного інституту. Кривий Ріг. 1957. № 2. С. 117-130. $266 \mathrm{c}$.

4. Добровольский И. А. Подбор пород для озеленения Кривбасса. Кривой Рог. 1966.

5. Енциклопедія Криворіжжжя. У 2-х т. / Упоряд. В.П.Бухтіяров. Кривий Ріг. Т. 1. 540 c., T. 2. 550 c.

6. Кондратюк Е. Н., Тарабрин В. П., Бурда Р. И., Хархота А. И. Промышленная ботаника. Киев. 1980. 260 с.

7. Кучерявий В. П. Фітомеліорація. Львів. 2003. 540 с.

8. Малахов Г. М. Шостак А. Г., Стариков Н. И. История горного дела в Криворожском бассейне. Киев. 1956. 342 с.

9. Мельник О., Балабанов С. Історична енциклопедія Криворіжжя. Кривий Ріг. 2007. $540 \mathrm{c}$.

10. Савосько В. М., Копич О. Ю. Ботаніко-екологічна характеристика деревно-чагарникових насаджень Довгинцівського дендропарку (м. Кривий Ріг) // Інтродукція рослин. 2012. № 1. С. 105-113.

11. Савосько В. М. Видовий склад та екоморфний спектр деревно-чагарникових насаджень парку «Веселі Терни» (м. Кривий Ріг) // Інтродукція рослин. 2013. № 2. С. 78-82.

12. Савосько В. М. Динаміка екоморфічного та біоморфічного спектрів дендрофлори колишнього ботанічного саду Криворізького державного педагогічного інституту // Екологія та ноосферологія. Дніпропетровськ. 2014. Т. 25. № 1-2. С. 37-45.

13. Савосько В. М., Квітко М. О. Сучасний стан основних насаджень Довгинцівського дендропарку (м. Кривий Ріг) // Промислова ботаніка.Донецьк. 2014. № 14. С. 106-114.

14. Савосько В. М., Товстоляк Н. В. Еколого-ботанічна обумовленість поширеності деревно-чагарникових видів у визначних парках та скверах історичного центру Криворіжжя // Інтродукція рослин. 2016. № 3. С. 85-95.

15. Сірик $\boldsymbol{A}$. $\boldsymbol{A}$. Природна стиглість лісових насаджень в степу України // Наукові праці Миколаївського державного гуманітарного університету імені Петра Могили: серія екологія. 2000. Т 1, N 6. С. 20-22.

16. Терлига Н. С. Данильчук О. В., Юхименко Ю. С., Федоровський В. Д., Данильчук Н. М. Культивована дендрофлора парків і скверів Кривого Рогу: історичні аспекти формування та сучасний стан // Вісник Харківського національного аграрного університету: серія біологія. 2015. N 2 (35). С. 93-101.

17. Товстенко Т. Д., Тямін М. Ю. Територіальний і розпланувальний розвиток м. Кривий Ріг // Праці Центру пам’яткознавства. Київ. 2009. N 16. С. 249-255.

18. Федоровський В. Д., Юхименко Ю. С., Данильчук О. В., Терлига Н. С., Данильчук Н. М. Дендрофлора зелених насаджень м. Кривий Ріг і перспективи іï збереження та збагачення // Вісті Біосферного заповідника «Асканія-Нова». Асканія-Нова. 2012. N 14. C. 405-408. 
19. Федоровський В. Д., Терлига Н. С. , Юхименко Ю. С., Данильчук О. В., Данильчук H. М., Лаптева O. B. Видовий склад та життєвий стан деревно-чагарникової рослинності парків та скверів м. Кривий Ріг // Інтродукція рослин. Київ. 2013. N 3. С. 73-79.

Надійшла до редколегії

УДК 581.1

Ю. В. Лихолат ${ }^{1}$, Н. О. Хромих ${ }^{1}$, Т. Ю. Лихолат ${ }^{1}$, М. І. Недзвецька О. А. Лихолат ${ }^{2}$ І В. В. Білик ${ }^{1}$, О. М. Боброва ${ }^{1}$

${ }^{1}$ Дніпровський національний університет імені Олеся Гончара

${ }^{2}$ Університет митної справи та фінансів

\section{ПРОМИСЛОВА ХАРАКТЕРИСТИКА ПЛОДІВ ПРЕДСТАВНИКІВ РОДУ ВЕRВERIS L.}

Проведено порівняльний аналіз плодо- та насіннсвої здатності представників роду Berberis L., що зростають в умовах ботанічного саду Дніпровського національного університету імені Олеся Гончара. Довжина насіння варіювала від 4,5 мм (B. canadensis) до 5,2 мм (B. declinata, B. amurensis), ширина - від 1,8 мм (B. amurensis, $B$. vulgares) до 2,1 мм (B. coreana). Найбільша маса 1000 шт. насінин відмічена у $B$. coreana. При порівнянні рівня загальної антиоксидантної здатності рослин найвищі показники були характерні для плодів $B$. koreana та $B$. x declinata, що перевищувало показники інших видів у 1,7-1,9 рази. Відносно низька концентрація антиоксидантів у плодах B. amurensis компенсусться більшою масою плодів цього виду.

Ключові слова: представники роду Berberis L., характеристика плодів, насіннєва здатність, антиоксидантна здатність плодів, перспективні види.

Ю. В. Лихолат ${ }^{1}$, Н. А. Хромых ${ }^{1}$, Т. Ю. Лихолат ${ }^{1}$, М. І. Недзвецкая ${ }^{1}$, О. А. Лихолат ${ }^{2}$, И. В. Билык', О. Н. Боброва ${ }^{1}$

Днепровский национальный университет имени Олеся Гончара

${ }^{2} У$ ниверситет таможенной службы и финансов

\section{ПРОМЫШЛЕННАЯ ХАРАКТЕРИСТИКА ПЛОДОВ ПРЕДСТАВИТЕЛЕЙ РОДА ВЕRВЕRIS L.}

Проведен сравнительный анализ плодо- и семенной способности представителей рода Berberis L., которые произрастают в условиях ботанического сада Днепровского национального университета имени Олеся Гончара. Длина семян варьировала от 4,5 мм (B. canadensis) до 5,2 мм (B. declinata, B. amurensis), ширина - от 1,8 мм (B. amurensis, B. vulgares) до 2,1 мм (B. coreana). Наибольшая масса 1000 шт. семян отмечена у $B$. coreana. При сравнении уровня общей антиоксидантной способности растений наивысшие показатели были характерны для плодов B. koreana и B. x declina$t a$, что превышало показатели других видов в 1,7-1,9 раза. Относительно низкая концентрация антиоксидантов в плодах $B$. amurensis компенсируется большей массой плодов этого вида.

Ключевые слова: представители рода Berberis L., характеристика плодов, семенная способность, антиоксидантная способность плодов, перспективные виды.

(C) Ю. В. Лихолат, Н. О. Хромих, Т. Ю. Лихолат, М. І. Недзвецька, О. А. Лихолат, I. В. Білик, О. М. Боброва, 2018 